\title{
Pengaruh Motivasi Kerja, Kemampuan Manajerial Kepala Sekolah, Dan Iklim Sekolah Terhadap Kinerja Guru Di Sekolah Menengah Pertama Negeri Se Kabupaten Pohuwato
}

\author{
Husain Maruf, Arfan Arsyad, Sitti Roskina Mas \\ Program Studi Magister Administrasi Pendidikan \\ Universitas Negeri Gorontalo, 2019 \\ email: Husain.Maruf@Gmail.Com
}

Received: 13 August 2021; Revised: 02 October 2021; Accepted: 14 December 2021

DOI: http://dx.doi.org/10.37905/aksara.8.1.291-302.2022

\begin{abstract}
Abstrak
Penelitian ini bertujuan untuk mengetahui (1) pengaruh motivasi kerja terhadap kinerja guru di Sekolah Menengah Pertama Negeri Se Kabupaten Pohuwato. (2) pengaruh kemampuan manajerial kepala sekolah terhadap kinerjaguru di Sekolah Menengah Pertama Negeri Se Kabupaten Pohuwato. (3) pengaruh iklim sekolah terhadap kinerjaguru di Sekolah Menengah Pertama Negeri Se Kabupaten Pohuwato. (4) pengaruh motivasi kerja terhadap iklim sekolah di Sekolah Menengah Pertama Negeri Se Kabupaten Pohuwato. (5) pengaruh kemampuan manajerial kepala sekolah terhadap iklim sekolah di Sekolah Menengah Pertama Negeri Se Kabupaten Pohuwato. Metode penelitian yang digunakan yakni metode kuantitatif. Teknik pengumpulan data yakni dengan melakukan penyebaran kuesioner pada responden yang telah memenuhi standar sampel penelitian. Teknik analisis data yang digunakan adalah analisis jalur (path analys). Hasil penelitian ini menunjukan bahwa (1) motivasi kerja berpengaruh langsung positif dan signifikan terhadap kinerja guru di Sekolah Menengah Pertama se Kabupaten Pohuwato. (2) kemampuan manajerial kepala sekolah berpengaruh langsung positif dan signifikan terhadap kinerja guru di Sekolah Menengah Pertama se Kabupaten Pohuwato. (3) iklim sekolah berpengaruh langsung positif dan signifikan terhadap kinerja guru di Sekolah Menengah Pertama se Kabupaten Pohuwato. (4) motivasi kerja berpengaruh langsung positif dan signifikan terhadap iklim sekolah di Sekolah Menengah Pertama se Kabupaten Pohuwato. (5) kemampuan manajerial kepala sekolah berpengaruh langsung positif dan signifikan terhadap iklim sekolah di Sekolah Menengah Pertama se Kabupaten Pohuwato.
\end{abstract}

Kata kunci: Motivasi Kerja, Kemampuan Manajerial, Iklim Sekolah, Kinerja Guru

\section{PENDAHULUAN}

Kinerja atau prestasi kerja guru harus selalu ditingkatkan mengingat tantangan dunia pendidikan untuk menghasilkan kualitas sumber daya manusia yang mampu bersaing di era global. Hasibuan (2001:94) yang menyebut kinerja sebagai prestasi kerja mengungkapkan bahwa "prestasi kerja adalah suatu hasil kerja yang dicapai seseorang dalam melaksanakan tugas-tugas yang dibebankan kepadanya yang disandar keatas kecakapan, pengalaman dan kesungguhan serta waktu. Di antara faktor penting yang mempengaruhi kinerja guru adalah ikllim kerja di sekolah. iklim sekolah adalah bagian dari organisasi yang baik langsung maupun tidak langsung akan berpengaruh terhadap perilaku guru. Untuk mendapatkan semua itu maka perusahaan ataupun organisasi harusdapat menciptakan iklim sekolah yang dapat mendukung terciptanya perilaku positif yang akan ditunjukkan oleh karyawan sebab iklim sekolahyang mendukung tersebut adalah salah satu kebutuhan bagi karyawan. Iklim kerja yang optimal ini akan mendoorng baiknya hasil capain kerja guru. Adanya berbagai masalah mengenai iklim kerja di sekolah tentunya ada faktor penting yang mempengaruhinya yang dalam hal ini 
bisa saja berasal dari guru itu sendiri maupun kepemimpinan di skeolah oleh kepala sekolah.

Motivasi mempunyai sifat yang tidak lepas dari sifat manusia yang secara individual mempunyai kualitas yang berbeda satu sama lain. Motivasi mempersoalkan bagaimana caranya gairah kerja guru, agar bekerja keras dengan menyumbangkan segenap kamampuan, pikiran keterampilan untuk mewujudkan tujuan pendidikan. Motivasi adalah suatu kekuatan potensial yang ada pada diri seseorang manusia, yang dapat dikembangkannya sendiri, atau dikembangkan oleh sejumlah kekuatan luar. Faktor lain yang mempengaruhi kinerja adalah kemampuan manajerial kepala sekolah dan iklim sekolah. Kemampuan manajerial kepala sekolah menurut Robin (2002:3) adalah "kemampuan untuk mempengaruhi suatu kelompok ke arah tercapainya tujuan". Setiap manusia pada hakikatnya adalah pemimpin dan setiap manusia akan diminta pertanggungjawaban atas kepemimpinanya kelak.

Hasil pengamatan awal di Sekolah Menengah Pertama Se Kabupaten Pohuwato menunjukkan bahwa kinerja guru masih rendah. Salah satunya adalah masih terdapat beberapa guru yang sangat kesulitan dalam melakukan pengembangan diri, kurangnya hubungan antara kepala sekolah dan guru, dan kurangnya motivasi yang diberikan kepala sekolah kepada guru, iklim sekolah kurang kondusif, hal ini disebabkan oleh adanya konflik antar guru di sekolah tersebut. Tingkat efektivitas komunikasi yang terjadi antara kepala sekolah dengan guru maupun guru dengan sesama guru lainnya belum optimal. Adanya jarak antara kepala sekolah dengan guru dan hubungan kerja antar guru kurang harmonis.

Fakta lain yang ditemukan adalah letak maupun penataan sarana dan prasarana juga kurang tepat. Hal ini juga berdampak pada kinerja mengajar guru tersebut. Guru tersebut menjadi tidak betah di sekolah ditandai dengan terlambat datang ke sekolah yang juga menyebabkan terlambat untuk mengajar di kelas. Kondisi guru yang tidak kompak serta perasaan tidak nyaman atas kondisi lingkungan fisik dan psikis menandakan bahwa iklim organisasi sekolah tersedut kurang kondusif. Hal ini tentu adalah salah satu hal yang menarik untuk diteliti, yakni bagaimana pengaruh iklim sekolah terhadap kinerja guru, sebab dari uarian peristiwa tersebut memperlihatkan bahwa iklim sekolah yang tidak kondusif membuat guru kurang maksimal dalam mengajar. Hal ini sebagiamana menurut temuan dari Selamat (2013) bahwa iklim kerja dari suatu organisasi akan meningkatkan kinerja dari guru dalam menjalankan tugas dan fungsinya dengan baik.

\section{METODE PENELITIAN}

Penelitian ini dilaksanakan pada guru Sekolah Menengah Pertama Negeri Se Kabupaten Pohuwato. Populasi dalam penelitian sebanyak 329 guru yang kemudian dengan rumus Taro Yamane diperoleh jumlah sampel sebanyak 77 orang guru. Analissi data dalam penelitian ini terdiri atas 2 yakni (1) analisis deskriptif dan (2) analisis jalur karena variabel kemampuan manajerila kepala sekolah. 


\section{HASIL PENELITIAN}

\section{A. Deskripsi Variabel Penelitian}

a. Variabel Kinerja guru (Y)

Hasil analisis deskriptif atas dasar jawaban responden untuk memperoleh kriteria dari variabel kinerja guru adalah sebagai berikut:

Tabel 1: Deskriptif Kinerja guru

\begin{tabular}{|ll|l|l|l|}
\hline & Frequency & Percent & $\begin{array}{l}\text { Cumulative } \\
\text { Percent }\end{array}$ \\
\hline \multirow{4}{*}{ Valid } & Baik & 28 & 36.4 & 36.4 \\
& Cukup Baik & 37 & 48.1 & 84.4 \\
& Kurang Baik & 12 & 15.6 & 100.0 \\
& Total & 77 & 100.0 & \\
\hline
\end{tabular}

Sumber: Data olahan SPSS 21, 2019

Guru yang memiliki kinerja yang baik sebanyak 28 orang atau sebesar 36,40\% sementara itu guru yang memiliki kinerja yang cukup baik sebanyak 37 orang atau sebesar 48,10\%. Serta guru yang memiliki kinerja yang kurang baik sebanyak 12 orang atau sebesar $15,60 \%$.

\section{b. Variabel Motivasi kerja (X1)}

Hasil analisis deskriptif atas dasar jawaban responden untuk memperoleh kriteria dari variabel Motivasi kerja adalah sebagai berikut:

Tabel 2: Deskriptif Motivasi kerja

\begin{tabular}{|ll|l|l|l|}
\hline & Frequency & Percent & $\begin{array}{l}\text { Cumulative } \\
\text { Percent }\end{array}$ \\
\hline \multirow{4}{*}{ Valid } & Tinggi & 42 & 54.5 & 54.5 \\
& Cukup Tinggi & 22 & 28.6 & 83.1 \\
& Rendah & 13 & 16.9 & 100.0 \\
& Total & 77 & 100.0 & \\
\hline
\end{tabular}

Sumber: Data olahan SPSS 21, 2019

Sebanyak 42 orang atau sebesar $54,50 \%$ guru yang memiliki motivasi yang tinggi. Sementara itu sebanyak 22 orang guru atau sebesar $28,60 \%$ memiliki motivasi cukup tinggi. Serta sebanyak 13 orang guru atau sebesar $16,90 \%$ memiliki motivasi rendah.

\section{c. Variabel Kemampuan manajerial kepala sekolah (X2)}

Hasil analisis deskriptif atas dasar jawaban responden untuk memperoleh kriteria dari variabel Kemampuan manajerial kepala sekolah adalah sebagai berikut: 
Tabel 3: Deskriptif Kemampuan manajerial kepala sekolah

\begin{tabular}{|ll|l|l|l|}
\hline & Frequency & Percent & $\begin{array}{l}\text { Cumulative } \\
\text { Percent }\end{array}$ \\
\hline \multirow{4}{*}{ Valid } & Baik & 13 & 16.9 & 16.9 \\
& Cukup Baik & 42 & 54.5 & 71.4 \\
& Kurang Baik & 22 & 28.6 & 100.0 \\
& Total & 77 & 100.0 & \\
\hline
\end{tabular}

Sumber: Data olahan SPSS 21, 2019

Guru yang merasakan adanya kepala sekolah dengan kemampuan manajerial yang baik sebanyak 13 orang atau sebesar $16,90 \%$ sementara itu guru yang merasakan adanya kepala sekolah dengan kemampuan manajerial yang cukup baik yakni sebanyak 42 orang atau sebesar 54,50\%. Serta guru yang merasakan adanya kepala sekolah dengan kemampuan manajerial yang kurang baik yakni sebanyak 22 orang atau sebesar $28,60 \%$.

d. Variabel Iklim sekolah (X3)

Hasil analisis deskriptif atas dasar jawaban responden adalah sebagai berikut:

Tabel 4: Deskriptif Iklim sekolah

\begin{tabular}{|ll|l|l|l|}
\hline & Frequency & Percent & $\begin{array}{l}\text { Cumulative } \\
\text { Percent }\end{array}$ \\
\hline \multirow{4}{*}{ Valid } & Kondusif & 16 & 20.8 & 20.8 \\
& Cukup Kondusif & 25 & 32.5 & 53.2 \\
& Kurang Kondusif & 36 & 46.8 & 100.0 \\
& Total & 77 & 100.0 & \\
\hline
\end{tabular}

Sumber: Data olahan SPSS 21, 2019

Iklim sekolah terdapat 3 kategori dimana guru yang merasakan adanya iklim sekolah yang kondusif sebanyak 16 orang atau sebesar 20,80\% sementara itu guru yang merasakan adanya iklim sekolah yang cukup kondusif sebanyak 25 orang atau sebesar $32,50 \%$. Serta guru yang merasakan adanya iklim sekolah yang cukup kondusif sebanyak 36 orang atau sebesar $46,80 \%$.

\section{B. Pengaruh Langsung dan Tidak Langsung}

Hasil analisis pengaruh langsung ditampilkan pada Tabel 5. sebagai berikut:

Tabel 5: Pengaruh Lansung

\begin{tabular}{|c|c|c|c|c|c|}
\hline \multirow[t]{2}{*}{ Model } & \multicolumn{2}{|c|}{$\begin{array}{l}\text { Unstandardized } \\
\text { Coefficients }\end{array}$} & \multirow{2}{*}{\begin{tabular}{|l}
$\begin{array}{l}\text { Standardized } \\
\text { Coefficients }\end{array}$ \\
Beta \\
\end{tabular}} & \multirow[t]{2}{*}{$\mathbf{t}$} & \multirow[t]{2}{*}{ Sig. } \\
\hline & B & Std. Error & & & \\
\hline \multirow{4}{*}{$\begin{array}{l}\text { (Constant) } \\
\text { Motivasi Kerja } \\
\text { Kemampuan Man } \\
\text { Iklim Sekolah }\end{array}$} & 23.545 & 6.524 & & 3.609 & .001 \\
\hline & .490 & .080 & .540 & 6.135 & .000 \\
\hline & .199 & .082 & .205 & 2.430 & .018 \\
\hline & .160 & .059 & .220 & 2.734 & .008 \\
\hline
\end{tabular}

Sumber: Data olahan SPSS 21, 2019 
Berdasarkan angka pada kolom Standardized Coefficients, maka persamaan struktural analisis jalurnya yakni sebagai beriku ini:

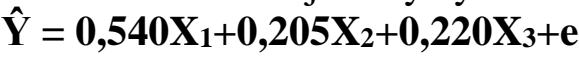

Selain hasil tersebut, pengaruh tidak langsung juga dapat diketahui dengan memposisikan iklim sekolah sebagai dependen dan variabel motivasi kerja dan kemampuan manajerial kepala sekolah sebagai independen. Hasil analisis ditampilkan pada Tabel 6 sebagai berikut:

Tabel 6: Pengaruh Tidak Langsung

\begin{tabular}{|c|c|c|c|c|c|}
\hline \multirow[t]{2}{*}{ Model } & \multicolumn{2}{|c|}{$\begin{array}{l}\text { Unstandardized } \\
\text { Coefficients }\end{array}$} & \multirow{2}{*}{$\begin{array}{l}\text { Standardized } \\
\text { Coefficients } \\
\text { Beta }\end{array}$} & \multirow[t]{2}{*}{$\mathbf{t}$} & \multirow[t]{2}{*}{ Sig. } \\
\hline & B & Std. Error & & & \\
\hline $\begin{array}{ll} & \text { (Constant) } \\
1 & \text { Motivasi Kerja } \\
& \text { Kemampuan Manajerial }\end{array}$ & $\begin{array}{l}28.277 \\
.408 \\
.132\end{array}$ & $\begin{array}{l}12.519 \\
.151 \\
.161\end{array}$ & $\begin{array}{l}.327 \\
.099\end{array}$ & $\begin{array}{l}2.259 \\
2.700 \\
2.316\end{array}$ & $\begin{array}{l}.027 \\
.009 \\
.017\end{array}$ \\
\hline
\end{tabular}

Sumber: Data olahan SPSS 21, 2019

Berdasarkan angka pada kolom Standardized Coefficients, maka persamaan struktural analisis jalurnya yakni sebagai beriku ini:

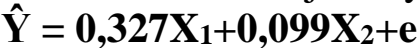

\section{Hasil Pengujian Hipotesis}

Berikut ini disajikan hasil analisis korelasi (r) disajikan berikut:

Tabel 7: Koefisien Korelasi

\begin{tabular}{|c|c|c|c|c|c|}
\hline & & $\begin{array}{l}\text { Kinerja } \\
\text { Guru }\end{array}$ & $\begin{array}{l}\text { Motivasi } \\
\text { Kerja }\end{array}$ & \begin{tabular}{l|} 
Kemampuan \\
Manajerial
\end{tabular} & $\begin{array}{l}\text { Iklim } \\
\text { Sekolah }\end{array}$ \\
\hline \multirow{5}{*}{$\begin{array}{l}\text { Pearson } \\
\text { Correlation }\end{array}$} & Kinerja Guru & 1.000 & .717 & .510 & .473 \\
\hline & Motivasi Kerja & .717 & 1.000 & 463 & .373 \\
\hline & $\begin{array}{l}\text { Kemampuan } \\
\text { Manajerial }\end{array}$ & .510 & .463 & 1.000 & .250 \\
\hline & Iklim Sekolah & .473 & .373 & .250 & 1.000 \\
\hline & Kinerja Guru & & .000 & .000 & .000 \\
\hline \multirow{5}{*}{$\begin{array}{l}\text { Sig. } \\
\text { tailed) }\end{array}$} & Motivasi Kerja & .000 & & .000 & .000 \\
\hline & $\begin{array}{l}\text { Kemampuan } \\
\text { Manaierial }\end{array}$ & .000 & .000 & & .014 \\
\hline & Iklim Sekolah & .000 & .000 & .014 & \\
\hline & Kinerja Guru & 77 & 77 & 77 & 77 \\
\hline & Motivasi Kerja & 77 & 77 & 77 & 77 \\
\hline \multirow[t]{2}{*}{$\mathrm{N}$} & $\begin{array}{l}\text { Kemampuan } \\
\text { Manajerial }\end{array}$ & 77 & 77 & 77 & 77 \\
\hline & Iklim Sekolah & 77 & 77 & 77 & 77 \\
\hline
\end{tabular}

Sumber: Data Olahan SPSS 21, 2019

Berdasarkan hasil analisis koefisien korelasi, maka dapat dilihat korelasi antara Motivasi kerja dengan kinerja guru yakni sebesar 0,717 kemudian variabel Kemampuan 
manajerial kepala sekolah dengan kinerja guru yakni sebesar 0,510. Korelasi variabel Iklim sekolah dengan kinerja guru yakni sebesar 0,473. Sehingga dapat digambarkan koefisien yang menyatakan determinasi dari total $\mathrm{X} 1, \mathrm{X} 2$, dan $\mathrm{X} 3$, terhadap $\mathrm{Y}$ atau $\mathrm{R}^{2} \mathrm{y}_{(\mathrm{X} 1, \mathrm{X} 2, \mathrm{X} 3)}$ adalah sebagai berikut:

$\mathrm{R}^{2} \mathrm{y}_{(\mathrm{X} 1, \mathrm{X} 2, \mathrm{X} 3)}=(0,540+0,205+0,220)\left[\begin{array}{l}0,717 \\ 0,510 \\ 0,473\end{array}\right]$

$\mathrm{R}^{2} \mathrm{y}_{(\mathrm{X} 1, \mathrm{X} 2, \mathrm{X} 3)}=(0.387+0.104+0.104)$

$\mathrm{R}^{2} \mathrm{y}_{(\mathrm{X} 1, \mathrm{X} 2, \mathrm{X} 3)}=0,596$ (Determinasi Multiple)

$\mathrm{P}_{\mathrm{y}} \varepsilon=1-0,596=0,404$ (pengaruh variabel lain)

Berdasarkan perhitungan dan analisis di atas dapat disajikan dalam bentuk Tabel berikut ini pengaruh dari variabel eksogen terhadap variabel endogen:

Tabel 8: Koefisien Jalur

\begin{tabular}{|c|c|c|}
\hline Variabel & Pengaruh & Besarnya Pengaruh \\
\hline \multirow{4}{*}{ Motivasi Kerja } & Langsung & 0.291 \\
\hline & Melalui X2 & 0.051 \\
\hline & Melalui X3 & 0.044 \\
\hline & Total X1 & 0.387 \\
\hline \multirow{4}{*}{$\begin{array}{l}\text { Kemampuan } \\
\text { Manajerial }\end{array}$} & Langsung & 0.042 \\
\hline & Melalui X1 & 0.051 \\
\hline & Melalui X3 & 0.011 \\
\hline & Total X2 & 0.104 \\
\hline \multirow{4}{*}{ Iklim Sekolah } & Langsung & 0.049 \\
\hline & Melalui X1 & 0.044 \\
\hline & Melalui X2 & 0.011 \\
\hline & Total X2 & 0.104 \\
\hline \multicolumn{2}{|c|}{ Pengaruh X1 terhadap X3 } & 0.327 \\
\hline \multicolumn{2}{|c|}{ Pengaruh X2 terhadap X3 } & 0.099 \\
\hline \multicolumn{2}{|c|}{ Pengaruh X1 terhadap Y } & 0.387 \\
\hline \multicolumn{2}{|c|}{ Pengaruh X2 terhadap Y } & 0.104 \\
\hline \multicolumn{2}{|c|}{ Pengaruh X3 terhadap Y } & 0.104 \\
\hline \multicolumn{2}{|c|}{ Determinasi Multiplier (Total X1+X2+X3) } & 0.596 \\
\hline \multicolumn{2}{|c|}{ Variabel Lain (1-R Square) } & 0.404 \\
\hline \multicolumn{2}{|c|}{ Adjusted R Square } & 0.579 \\
\hline \multicolumn{2}{|c|}{ Variabel Lain (1-Adjusted R Square) } & 0.421 \\
\hline
\end{tabular}

Sumber: Data Olahan SPSS 21, 2019

Berdasarkan Tabel di atas dapat dilihat bahwa pengaruh langsung dari variabel motivasi kerja dan kemampuan manajerial kepala sekolah masih lebih besar dibandingkan pengaruh tidak langsung (melalui variabel mediasi/iklim sekolah). Hal ini menunjukan bahwa iklim sekolah mampu mampu menjadi mediasi yang optimal dalam meningkatkan pengaruh dari variabel motivasi kerja dan kemampuan manajerial kepala sekolah terhadap kinerja guru meskipun iklim kerja memiliki hasil yang paling signifikan jika di posisi sebagai variabel bebas bersama motivasi kerja dan kemampuan manajerial kepala sekolah. 
Berdasarkan Tabel di atas pula, maka dapat digambarkan jalur struktur variabel $\mathrm{X} 1, \mathrm{X} 2$, dan $\mathrm{X} 3$ terhadap Y berikut ini:

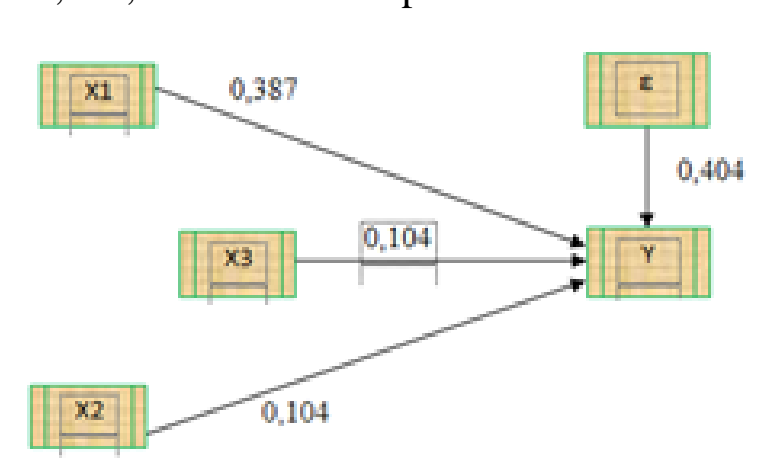

Gambar 1: Struktur Path Analisis Pengaruh X1, X2, dan X3 Terhadap Y

Adapun gambaran konstruk mengenai pengaruh motivasi kerja dan kemampuan manajerial kepala sekolah terhadap iklim sekolah disajikan sebagai berikut ini:

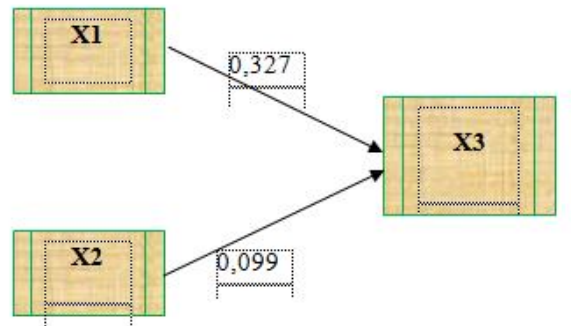

\section{Gambar 2: Struktur Pengaruh X1 dan X2 Terhadap X3}

Berdasarkan gambar kedua gambar struktur path di atas maka dapat dilakukan hasil pengujian hipotesis. Dalam rangka mendapatkan kesimpulan apakah menerima atau menolak Ho, terlebih dahulu harus ditentukan nilai $\mathrm{t}_{\text {Tabel }}$ yang akan digunakan. Nilai $t_{T a b e l}$ ini bergantung pada besarnya df (degree of freedom) serta tingkat signifikansi yang digunakan. Dengan menggunakan tingkat signifikansi sebesar 5\% dan nilai df seebsar $\mathrm{n}-\mathrm{k}-1=77-3-1=73$ diperoleh nilai $\mathrm{t}_{\text {Tabel }}$ sebesar 1 ,993. Hasil pengujian dijabarkan sebagai berikut ini:

\section{1) Pengaruh Motivasi kerja Terhadap kinerja guru}

Nilai $t_{\text {hitung }}$ yang diperoleh jauh lebih besar dari nilai $\mathrm{t}_{\text {Tabel. }}$ Nilai signifikansi Motivasi kerja lebih kecil dari nilai probabilitas 0,05 , atau nilai $(0,000<0,05)$, maka motivasi kerja berpengaruh langsung positif dan signifikan terhadap kinerja guru di Sekolah Menengah Pertama se Kabupaten Pohuwato.

\section{2) Pengaruh Kemampuan manajerial kepala sekolah terhadap kinerja guru}

Nilai $t_{\text {hitung }}$ yang diperoleh lebih besar dari nilai $\mathrm{t}_{\text {Tabel. }}$. Nilai signifikansi Kemampuan manajerial kepala sekolah lebih kecil dari nilai probabilitas 0,05 , atau nilai $(0,018<0,05)$, maka kemampuan manajerial kepala sekolah berpengaruh langsung positif dan signifikan terhadap kinerja guru di Sekolah Menengah Pertama se Kabupaten Pohuwato.

\section{3) Pengaruh Iklim sekolah Terhadap kinerja guru}

Nilai $t_{\text {hitung }}$ yang diperoleh jauh lebih besar dari nilai $\mathrm{t}_{\text {Tabel }}$. Nilai signifikansi Iklim sekolah lebih kecil dari nilai probabilitas 0,05 , atau nilai $(0,008<0,05)$, maka iklim sekolah berpengaruh langsung positif dan signifikan terhadap kinerja guru di Sekolah Menengah Pertama se Kabupaten Pohuwato. 


\section{4) Pengaruh Motivasi kerja Terhadap iklim sekolah}

Nilai $t_{\text {hitung }}$ yang diperoleh jauh lebih besar dari nilai $\mathrm{t}_{\text {Tabel. }}$ Nilai signifikansi Motivasi kerja lebih kecil dari nilai probabilitas 0,05, atau nilai $(0,009<0,05)$, maka motivasi kerja berpengaruh langsung positif dan signifikan terhadap iklim sekolah di Sekolah Menengah Pertama se Kabupaten Pohuwato.

\section{5) Pengaruh Kemampuan manajerial kepala sekolah terhadap iklim sekolah}

Nilai thitung yang diperoleh lebih besar dari nilai $t_{\text {Tabel. Nilai signifikansi }}$ Kemampuan manajerial kepala sekolah lebih kecil dari nilai probabilitas 0,05 , atau nilai $(0,017<0,05)$, maka kemampuan manajerial kepala sekolah berpengaruh langsung positif dan signifikan terhadap iklim sekolah di Sekolah Menengah Pertama se Kabupaten Pohuwato.

\section{PEMBAHASAN}

\section{Pengaruh Motivasi kerja terhadap kinerja guru}

Hasil penelitian menunjukkan bahwa motivasi kerja berpengaruh langsung positif dan signifikan terhadap kinerja guru di Sekolah Menengah Pertama se Kabupaten Pohuwato. Pengaruh positif ini menunjukan bahwa motivasi kerja guru yang tinggi akan mendorong baiknya hasil kerja guru sedangkan pengaruh yang signifikan menunjukan adanya pengaruh yang kuat dari motivasi kerja terhadap kinerja guru. Sehingga sebaiknya guru di Sekolah Menengah Pertama se Kabupaten Pohuwato terus berupaya untuk meningkatkan motivasi kerja dengan menumbuhkan kesadaran tugas dan tanggung jawab yang diamanhkan kepada guru sebagai pendidik di sekolah. Sementara itu hasil penelitian berdasarkan analisis deskriptif ditemukan bahwa guru di Sekolah Menengah Pertama Negeri di Kabupaten Pohuwato cenderung memiliki semangat kerja yang tinggi untuk melaksanakan tugas dan fungsinya sebagai pengajar di sekolah. Adanya semangat guru yang tinggi dalam menjalankan amanah tugasnya maka akan menunjang baiknya hasil capain kerja dari guru tersebut.

Hasil penelitian ini sesuai dengan pernyataan dari Mulyasa (2004:120) bahwa para pegawai (guru) akan bekerja dengan sungguh-sungguh apabila memiliki motivasi yang tinggi. Apabila memiliki motivasi yang positif, ia akan memperlihatkan minat, mempunyai perhatian, dan ingin ikut serta dalam suatu tugas atau kegiatan".

Hasil ini juga sesuai dengan temuan dari Supardi (2014: 50) bahwa kinerja seseorang sangat dipengaruhi oleh faktor kemampuan (ability), motivasi (motivation), dan kesempatan (opportunity), yaitu performance artinya kinerja merupakan fungsi dari kemampuan, motivasi dan kesempatan. Sebagai tenaga profesional kependidikan guru memiliki motivasi kerja yang berbeda antara guru yang satu dengan lainnya. Hal ini kelak akan berakibat adanya perbedaan kinerja guru dalam meningkatkan mutu pendidikan.

\section{Pengaruh Kemampuan manajerial kepala sekolah terhadap kinerja guru}

Hasil penelitian menunjukkan bahwa kemampuan manajerial kepala sekolah berpengaruh langsung positif dan signifikan terhadap kinerja guru di Sekolah Menengah Pertama se Kabupaten Pohuwato. Pengaruh positif namun tidak signfikan menunjukan bahwa kepala sekolah yang memiliki kemampuan manajerial akan memberikan kontribusi baik dalam peningkatan kinerja guru meskipun dampaknya belum begitu 
besar. Pentingnya bagi kepala sekolah untuk terus meningkatkan kemampuannya dalam hal manajerial dengan cara mengikuti pendidikan dan pelatihan khusus kepala sekolah.

Hasil ini sesuai dengan pernyataan dari Wahjosumidjo (2010) bahwa kemampuan manajerial kepala sekolah adalah kemampuan internal yang dimiliki oleh seorang kepala sekolah dalam memberikan bimbingan dan mengarahkan para guru, staf, dan para siswa serta memberikan dorongan memacu dan semangat dan rasa percaya diri demi kemajuan dalam menjcapi tujuan organisasi sekolah.

Hal yang sama juga diungkapkan oleh Gibson, et al. (2009: 13), bahwa sifat dari manajerial untuk mengkoordinasikan pekerjaan individu, kelompok, dan organisasi dengan melakukan empat fungsi manajemen: perencanaan, pengorganisasian, memimpin dan mengendalikan. Kepala sekolah dalam rangka melakukan peran dan fungsinya sebagai manajer harus memiliki perencanaan yang baik dalam meningkatkan kinerja dari guru.

\section{Pengaruh Iklim sekolah terhadap kinerja guru}

Hasil penelitian menunjukkan bahwa iklim sekolah berpengaruh langsung positif dan signifikan terhadap kinerja guru di Sekolah Menengah Pertama se Kabupaten Pohuwato. Pengaruh positif dan signifikan menunjukan bahwa iklim sekolah sangat memberikan dampak yang berarti dan baik bagi peningkatan hasil capaian kerja guru karena iklim akan menumbuhkan kerja sama antar guru. Pentingnya bagi warga sekolah baik guru, tata usaha dan kepala sekolah untuk menumbuhkan sikap kerja sama dalam menjalankan tugas dan saling membantu dalam pemecahan masalah sehingga hal ini akan berdampak baik pada hasil kinerja baik secara individu maupun satu kesatuan di sekolah sebagai prestasi bersama.

Temuan penelitian ini sesuai dengan temuan dari Sapali (2017) bahwa terdapat pengaruh iklim sekolah terhadap pengelo laan pendidikan karakter, Terdapat pengaruh antara komitmen kerja guru terhadap pengelo laan pendidikan karakter, terdapat pengaruh antara iklim sekolah dan komitmen kerja guru terhadap kinerja guru di sekolah Dasar Negeri Se Kota Gorontalo. Terdapat pengaruh langsung yang positif dan signifikan iklim sekolah terhadap kinerja guru di sekolah Dasar Negeri Se Kota Gorontalo, Terdapat pengaruh langsung yang positif dan signifikan komit men guru terhadap kinerja guru di sekolah Dasar Negeri Se Kota Gorontalo , terdapat pengaruh langsung yang positif dan signifi kan antara iklim sekolah dan komitmen kerja guru terhadap kinerja guru di sekolah Dasar Negeri Se Kota Gorontalo.

Hasil penelitian dari pengujian deskriptif ditemukan bahwa guru di Sekolah Menengah Pertama Negeri di Kabupaten Pohuwato memiliki hasil capaian kerja yang optimal terutama dalam kegiatan pembelajaran. Guru dengan kinerja yang baik akan mampu untuk menghasilkan peserta didik dengan hasil belajar yang optimal pula bahkan menjadi kebanggan dan prestasi bagi skeolah untuk lebih berkembang. Sehingga secara keseluruhan hasilnya mendukung penelitian yang dilakukan oleh Selamat, dkk (2013) yang menemukan bahwa iklim organisasi ditemukan menjadi faktor signifikan yang dapat mempengaruhi kinerja guru. Dalam hal dimensi iklim organisasi, satu aspek dari perilaku kepemimpinan kepala sekolah dan perilaku guru: dorongan dan hambatan ditemukan menjadi faktor penting dalam meningkatkan kinerja guru.. Sehingga terdapat korelasi yang tinggi antara iklim kerja dengan kinerja dari guru. 


\section{Pengaruh Motivasi kerja terhadap iklim sekolah}

Hasil penelitian menunjukkan bahwa motivasi kerja berpengaruh langsung positif dan signifikan terhadap iklim sekolah di Sekolah Menengah Pertama se Kabupaten Pohuwato. Pengaruh positif dan signifikan ini menunjukan bahwa motivasi kerja dari guru akan menjadi stimulus bagi guru untuk menciptakan iklim sekolah yang kondusif baik untuk pekerjaanya dalam administratif sekolah maupun tugas dalam pembelajaran.

Hasil ini sesuai dengan pernyataan dari Hariandja (2005: 36) bahwa Seorang kepala sekolah dalam suatu organisasi sekolah harus dapat menciptakan Budaya Sekolah yang serasi dengan para bawahannya juga termasuk dalam membina kerjasama, mengarah dan mendorong gairah kerja para bawahan sehingga tercipta motivasi positif yang akan menimbulkan niat dan usaha (kinerja) yang maksimal. Iklim sekolah adalah sekumpulan pola perilaku yang melekat secara keseluruhan pada diri setiap kepala sekolah dalam suatu organisasi sekolah.

Hasil ini sesuai dengan pernyatan dari Uno (2012: 4) bahwa motivasi dapat dikatakan sebagai perbedaan antara dapat melaksanakan dan mau melaksanakan. Motivasi lebih dekat pada mau melaksanakan tugas untuk mencapai tujuan. Motivasi adalah kekuatan baik dari dalam maupuan dari luar yang mendorong seseorang untuk mencapai tujuan tertentu yang telah ditetapkan sebelumnya. Atau dengan kata lain, motivasi dapat di artikan sebagai dorongan mental terhadap perorangan atau orangorang sebagai anggota msyarakat. Motivasi dapat juga diartikan sebagai proses untuk mencoba mempengaruhi orang atau orang-orang yang dipimpinnya agar melakukan pekerjaan yang di inginkan sesuai dengan tujuan tertentu yang ditetapkan lebih dahulu.

\section{Pengaruh Kemampuan manajerial kepala sekolah terhadap iklim sekolah}

Hasil penelitian menunjukkan bahwa kemampuan manajerial kepala sekolah berpengaruh langsung positif dan signifikan terhadap iklim sekolah di Sekolah Menengah Pertama se Kabupaten Pohuwato. Pengaruh positif tidak signifikan ini menunjukan bahwa peran kepala sekolah terutama dalam hal manajerialnya belum memberikan dampak yang kuat untuk peningkatan iklim sekolah. Sheingga kepala sekolah harus terus menjalin kerja sama, komunikasi dan koordinasi dalam berbagai kesempatan bahkan pada pengambilan keputusan

Hasil ini sesuai dengan pernyhataan dari Aqib (2002: 36) bahwa Kemampuan manajerial dan iklim sekolah adalah pengaruh yang akan menimbulkan pemahaman tersendiri yang akan berpengaruh terhadap kondisi psikologis bawahan, ada bawahan yang melihat, mengamati dan mengikuti perilaku pemimpin yang ditampilkan atasan dirasakan sebagai suatu yang diharapkan maka akan memiliki dampak yang lebih baik terhadap motivasi guru, sebaliknya apabila perilaku pemimpin yang ditampilkan atasan sebagai sesuatu yang tidak sesuai dengan harapannya maka akan berpengaruh kurang baik terhadap motivasi kerja guru di sekolah.

Hasil penelitian dari analisis deskriptif menunjukan bahwa Iklim kerja yang ada di Sekolah Menengah Pertama Negeri di Kabupaten Pohuwato cenderung kurang kondusif namun demikian yang merasakan kondusif dan cukup kondusif masih lebih besar. Sehingga hal ini menunjukan bahwa Sekolah Menengah Pertama Negeri di Kabupaten Pohuwato masih memerlukan perhatian penuh dari segenap pihak agar saling ambil bagian dalam menciptakan iklim sekolah yang kondusif. 
Secara keseluruhan maka hasil ini menunjukan pentingnya kemampuan manajerila kepala skelah dalam menciptakan iklim yang kondusif. Hal ini sebagaimana dipertegas oleh pernyataan Danim (2012: 204) bahwa kepala sekolah harus memiliki kemampuan relasional untuk membangun relasi dan kolaborasi dengan berbagai pihak untuk tujuan-tujuan sosial atau produktif. Dalam lingkungan internal lembaga sekolah, diperlukan peran kepala sekolah sebagai inisiator dalam membangun iklim sekolah yang kondusif.

\section{KESIMPULAN}

Berdasarkan hasil penelitian dan pembahasan di atas, maka dapat ditarik simpulan bahwa:

1. Motivasi kerja berpengaruh langsung positif dan signifikan terhadap kinerja guru di Sekolah Menengah Pertama se Kabupaten Pohuwato dengan nilai determinan sebesar $38,70 \%$.

2. Kemampuan manajerial kepala sekolah berpengaruh langsung positif dan signifikan terhadap kinerja guru di Sekolah Menengah Pertama se Kabupaten Pohuwato dengan nilai determinan sebesar 10,40\%.

3. Iklim sekolah berpengaruh langsung positif dan signifikan terhadap kinerja guru di Sekolah Menengah Pertama se Kabupaten Pohuwato dengan nilai determinan sebesar $10,40 \%$.

4. Motivasi kerja berpengaruh langsung positif dan signifikan terhadap iklim sekolah di Sekolah Menengah Pertama se Kabupaten Pohuwato dengan nilai determinan sebesar 32,70\%.

5. Kemampuan manajerial kepala sekolah berpengaruh langsung positif dan signifikan terhadap iklim sekolah di Sekolah Menengah Pertama se Kabupaten Pohuwato dengan nilai determinan sebesar 9,90\%.

\section{DAFTAR PUSTAKA}

Hampton. 1993. Psikologi Kepemimpinan. Surabaya: Usaha Nasiona

Handoko, Hani. 2000. Manajemen Strategis Kepemimpinan Pendidikan. Yogyakarta: IRCISOD.

Hermawan, Aan. 2011. Administrasi Pendidikan. Jakarta: Alfabeta

Kusmintardjo . 2009. Pengantar Pendidikan. Jakarta: PT Raja Grafindo Persada.

Luthans, Fred. 2002. Organizational Behavior. Singapore Mc Graw - Hill

Masaong dan Tilome. 2011. Pelaksanaan Supervisi Klinis Untuk Meningkatkan Kinerja Pegawai. Bandung: Alfabeta

Mulyasa. 2004. Kebijakan pendidikan Era OtonomiDaerah.Jakarta: RajaGrafindo Persada.

Nanus, Burt, 2001, "Kepemimpinan Visioner: Menciptakan Kesadaran akan Arah dan Tujuan di dalam Organisasi. Yogyakarta: Ar-Ruzz Media

Nawawi, H, Hadari. 2008. Manajemen Sumber Daya Manusia. Yogyakarta: Gadja Mada University Press.

Nurhadi.2009. Kebijakan Publik Teori dan Proses. Yogyakarta: Media Pressindo

Patricia. 2007. Total Quality Management. Yogyakarta: Andi Offset.

Triguno, P. 2002. Manajemen Strategik Dalam peningkatan Mutu Pendidikan. Bandung: Alfabeta 
Umar, H. 2004. Manajemen Personalia, Edisi Ketiga. Jakarta:Erlangga

Uno, B. Hamzah. 2000. Menciptakan Proses Belajar Mengajar yang Kreatif dan Efektif. Jakarta: Bumi Aksara

Usman. A. Dale,2008, Kinerja, Jakarta: PT Elex Media Komputindo,.

Wahab Aziz Abdul. 2011. Anatomi Organisasi dan Kepemimpinan Pendidikan. Jakarta: Alfabeta. 